\title{
Using Calcicolous and Corticolous Lichens to Assess Lead and Cadmium Air Pollution of the Moroccan Atlantic Coast Safi-Essaouira
}

\author{
Essilmi Mohamed*, Loudiki Mohammed, El Gharmali Abdelhay \\ Cadi Ayyad University, Laboratory of Microorganisms Biology and Biotechnology, \\ Faculty of Sciences Semlalia, Marrakech, Morocco
}

Received: 13 November 2018

Accepted: 3 January 2019

\begin{abstract}
Air pollution by metallic trace elements (MTE) has evolved in recent years in Moroccan cities especially those with significant industrial activities. Biological tools, especially the use of lichens as a bioindicator of heavy metal air pollution, have been receiving world-wide attention. This study aims to evaluate atmospheric pollution of the Moroccan Atlantic coastline Safi-Essaouira using lichen as monitors of atmospheric metal contamination. Thus, two trace elements (lead and cadmium) were analysed through biomonitoring by two calcicolous lichens, Xanthoria calcicola and Ramalina pollinaria, and two corticoulous lichens, Xanthoria parietina and Ramalina lacera. The results show that the concentrations of the two trace elements in lichen samples were relatively higher in urban and industrial sites than in rural sites. The maximum lead levels were $30.18 \mathrm{mg} / \mathrm{kg}$, $4.36 \mathrm{mg} / \mathrm{kg}, 9.79 \mathrm{mg} / \mathrm{kg}$ and $3.35 \mathrm{mg} / \mathrm{kg}$ respectively in Xanthoria calcicola, Ramalina pollinaria, Xanthoria parietina and Ramalina lacera. The maximum cadmium levels were $0.53 \mathrm{mg} / \mathrm{kg}$, $0.19 \mathrm{mg} / \mathrm{kg}, 0.58 \mathrm{mg} / \mathrm{kg}$ and $0.37 \mathrm{mg} / \mathrm{kg}$ respectively in Xanthoria calcicola, Ramalina pollinaria, Xanthoria parietina and Ramalina lacera. Three levels of air quality have been deduced in the studied area: poor air quality in the industrial site of Safi city, medium air quality in peri-urban areas, and good air quality in rural sites.
\end{abstract}

Keywords: air pollution, metallic trace elements, bioaccumulation, lichen

\section{Introduction}

In $2016,91 \%$ of the world population was living in places where the World Health Organization air quality guideline levels were not met [1]. Poor air quality has a negative impact on human health and the environment [2-4]. In Morocco, the cost of air degradation and its impacts have been estimated at 3.6 billion dirhams per year, which represents about 1.03 per cent of Morocco's GDP [5].

*e-mail: mohamed.essilmi@ced.uca.ma 
Physical and chemical approaches to measuring air pollution have continued to grow and become more efficient over time; however, because of their high cost, the bioaccumulation of atmospheric metal trace elements (MTE) is frequently evaluated by analysing the environment of biomonitors, such as plant leaves, mosses, or lichens. Hundreds of studies over the past 30 years have confirmed that lichens are among the most reliable accumulators of inorganic airborne contaminants [6]. They are organisms that lack specialized structures for the exchange of water and gas and thus absorb gases and water with substances dissolved over a large part of their outer surface. In many species, the numerous branches of the thallus and the large intercellular spaces facilitate the trapping of airborne pollutants such as MTE. The chemical composition of lichens therefore largely reflects the availability of pollutants in the environment [6].

The air pollution varies depending on many factors such as degree of industrialization, population density, traffic density and climate variables [4, 7-9]. The Atlantic coast of Morocco at Safi-Essaouira includes two urbanized areas (the cities of Safi and Essaouira) and less urbanized areas. Since the 1960s, it has been home to a major industrial phosphate processing complex located $7 \mathrm{~km}$ south of Safi, which is accused of being one of the contributors to the deterioration of the air quality of the city. In 2017, the lichenic bioindication approach and the use of the poleotolérance index and the eutrophication index [10] enabled Essilmi et al. [11] to highlight a deterioration of air quality in the industrial zone of Safi.

Contamination generally leads to a decrease in lichen biodiversity [12], but thanks to specific biological potential, some lichens have managed to support polluted environments [13]. Various studies have documented various responses of lichens to pollutants [14-16], among these reactions: changes in external morphology, disturbances of physiological processes, ultrastructural changes and decreased intraspecific sexual reproduction capacity [17-18]. In addition to these changes, the elemental composition of lichens reflects the concentrations of pollutants and heavy metals in the polluted environment [19-22].

The main objective of this work is to collect samples of four species of lichens characteristic of the Atlantic coast of Morocco (Safi-Essaouira) in order to quantitatively determine the bioaccumulation of two metallic trace elements $(\mathrm{Pb}$ and $\mathrm{Cd})$ in their thalli and evaluate the air quality of this part of Morocco. Two corticolous species (Xanthoria parietina and Ramalina lacera) and two calcicolous species ( Xanthoria calcicola and Ramalina pollinaria) have been studied. This is the first initiative of its kind in this region of study.

\section{Materials and Methods}

\author{
Study Sites
}

Located in the west of Morocco, the Atlantic coastline from the municipality of Oualidia $(60 \mathrm{~km}$ north of Safi city) to the province of Essaouira extends over a length of $200 \mathrm{~km}$. Eight study sites were selected (Fig. 1).

\section{Lichen Material}

In Morocco, previous studies used epiphytic lichens such as Parmlia sp and Xanthoria parietina as bioaccumulative models [23-25]. The lichenic bioccumulation approaches have used and still mainly use corticolous lichens. The reason why we chose two saxicolous species is the nature of the biotope of this study area harboring few corticolous and terricolous lichens, but showing a remarkable presence of saxicolous-calcicolous lichens. The dominance of limestone rocks combined with a semi-arid climatic character is such that this region is colonized mainly by calcicolous lichens [11].

The lichens sampling targeted two saxicolous species installed on calcareous rock formations: Xanthoria calcicola and Ramalina pollinaria (the only Ramalina calcitolerant); and two epiphytic species whose porophyte is acacia dealbata: Xanthoria parietina and Ramalina lacera (former nomination Ramalina duriaei).

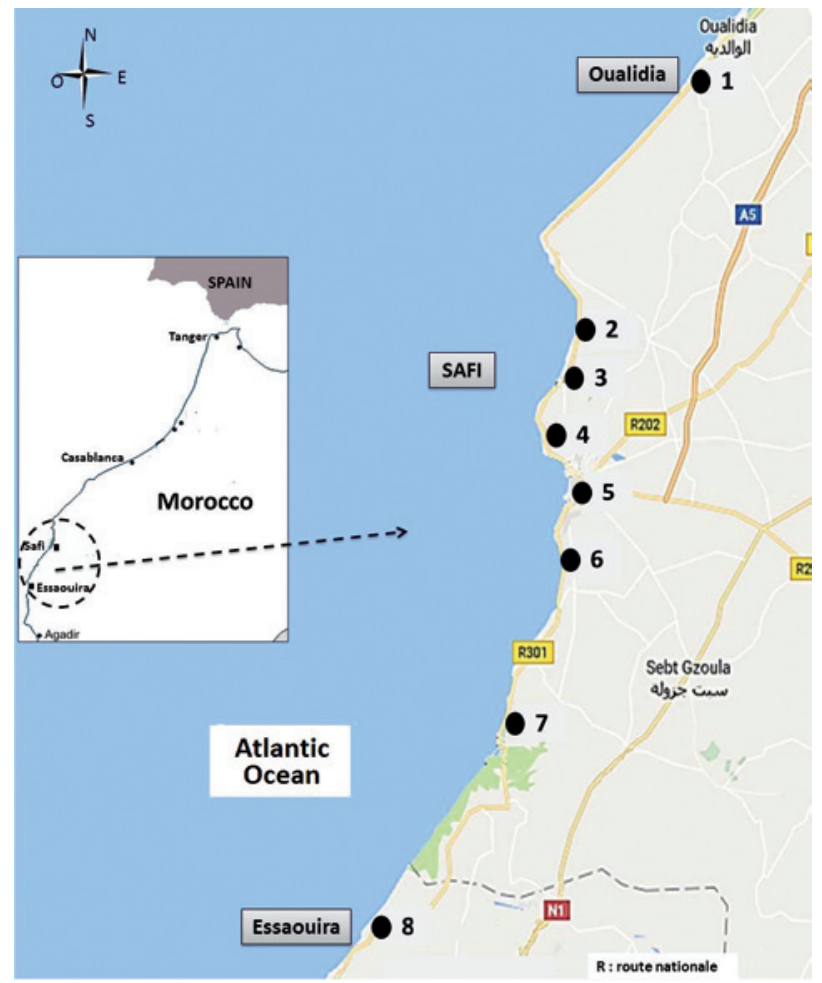

Fig. 1. Location of the Safi-Essaouira coastline and the eight study sites (1 to 8 ). 


\section{Measurement and Statistical Analysis}

The determination of heavy metal content accumulated in lichens was designed according to the lichen analysis standard: NF X43-904 (AFNOR). In the laboratory, the lichens were dried at $105^{\circ} \mathrm{C}$ for 24 hours, a dry weight of $2 \mathrm{~g}$ was milled in an agate mortar and the resulting powder was calcined at $550^{\circ} \mathrm{C}$ for 5 hours. After calcination, the sample undergoes oxidation with $5 \mathrm{ml}$ of $\mathrm{H}_{2} \mathrm{O}_{2}$ at $30 \% \mathrm{w} / \mathrm{w}(110 \mathrm{vol}$.) and then a hot acid attack with a mixture of $50 \% \mathrm{HCl}(37 \%$ PA-ACS-ISO) and $50 \% \mathrm{HNO}_{3}(65 \%$ PA-ISO). The assay of standard solutions and samples was performed using an "Ice 3000 SERIES AA" atomic absorption spectrometer (Thermo Fisher Scientific Corporation) using the airacetylene flame.

Four replicates were completed for each sample. The metallic trace elements content of more than 64 lichen samples, from urban and rural areas, was explored and field campaigns were conducted in 2016 and 2017. A database was created and its management, data processing, and statistical analysis were carried out using IBM SPSS statistics 20.0 software, and the R software version 3.4.3.

\section{Results}

\section{Variations in Lead and Cadmium Contents}

Fig. 2 shows the spatial variations in lead and cadmium concentrations: the maximum lead levels were $30.18 \mathrm{mg} / \mathrm{kg}$ of dry matter, $4.36 \mathrm{mg} / \mathrm{kg}$ d.m, $9.79 \mathrm{mg} / \mathrm{kg}$ d.m and $3.35 \mathrm{mg} / \mathrm{kg}$ d.m. respectively in Xanthoria calcicola, Ramalina pollinaria, Xanthoria parietina and Ramalina lacera.

The maximum cadmium levels were $0.53 \mathrm{mg} / \mathrm{kg}$ of dry matter, $0.19 \mathrm{mg} / \mathrm{kg}$ d.m, $0.58 \mathrm{mg} / \mathrm{kg}$ d.m and $0.37 \mathrm{mg} / \mathrm{kg}$ d.m respectively in Xanthoria calcicola, Ramalina pollinaria, Xanthoria parietina and Ramalina lacera.

High levels of lead and cadmium were recorded in the lichens harvested in the industrial zone of Safi (site S4). These levels decrease in the city center samples (site S3) and continue to decrease in sites S2, S5, S6, $\mathrm{S} 7$, and S8. The lowest levels of lead and cadmium are recorded in the S1 site samples.

The maximum levels recorded in Safi in the four species are similar to some examples of bioaccumulation recorded in different regions of the world (Table 1). However, in other cases the levels are much higher than those recorded at Safi. In the S4 site Xanthoria calcicola reached a lead level of $30.18 \mathrm{mg} / \mathrm{kg} \mathrm{d.m.,} \mathrm{but}$ in 1995 a relatively high rate of $125 \mathrm{mg} / \mathrm{kg}$ d.m of lead was recorded in this species in Macedonia. In the same reflection, Ramalina lacera in Safi does not exceed the rate of $0.37 \mathrm{mg} / \mathrm{kg}$ d.m of cadmium, but in 1998 a rate
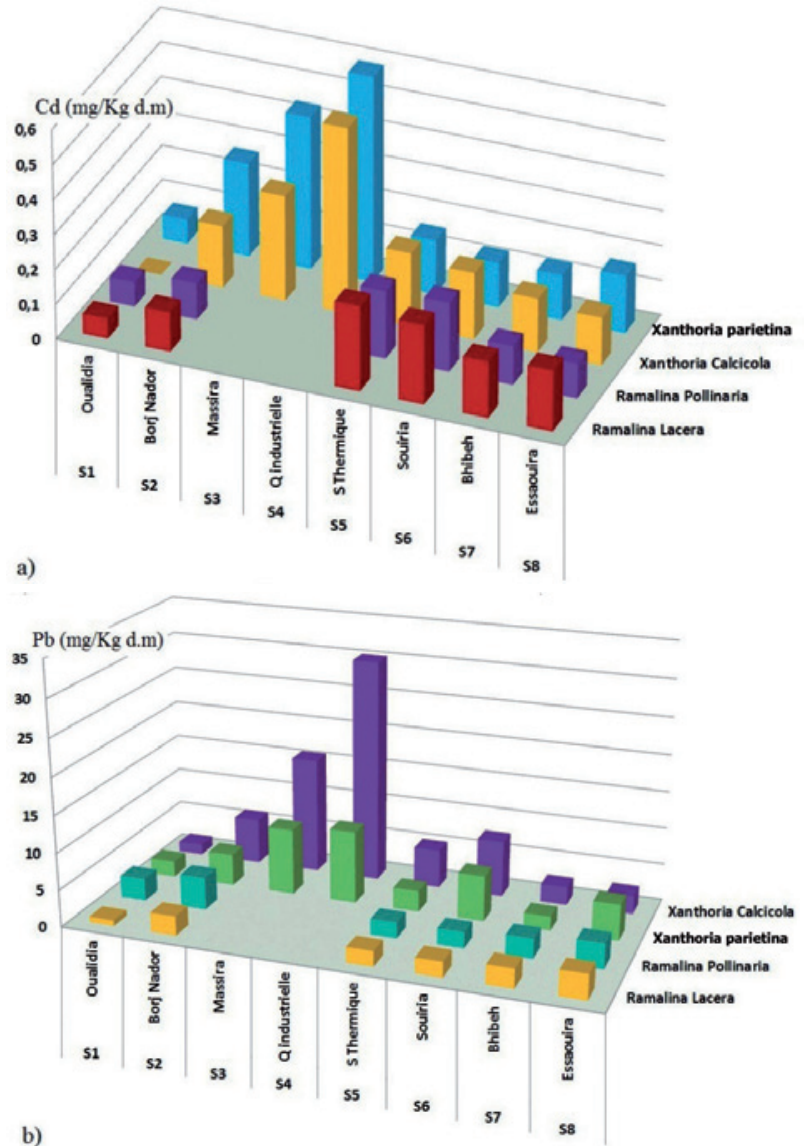

Fig. 2. a) Spatial variation of mean cadmium concentration in Xanthoria calcicola, and Ramalina pollinaria, Xanthoria parietina and Ramalina lacera. b) Spatial variation of mean lead concentration in Xanthoria calcicola, and Ramalina pollinaria, Xanthoria parietina and Ramalina lacera. S1 to S8: Study sites.

of $8.5 \mathrm{mg} / \mathrm{kg}$ d.m of Cd was measured in this species in Israel.

\section{Correlation Analysis}

The principal components analysis ACP allowed the structuring of the data into two components (Fig. 3a):

- A component grouping together the phenomenon of bioaccumulation in the studied lichens, this component is more or less correlated with certain ecological factors: altitude and north latitude (LatN on the figure).

- The second component, isolating the studied sites (Distpoll on figure), is correlated with the rest of the considered ecological factors: average annual precipitation, average annual temperature, relative humidity, and western latitude.

In order to group the sites that recorded similar bioaccumulation values, we adopted a hierarchical clustering on principal components (HCPC) classification [33], which allowed the construction of a factorial map and a 3D graph combining the hierarchical classification and the factor plan (Fig. 3b). 
Table 1. Comparison of the average maximum rates of lead and cadmium content in lichens studied in Safi with other regions of the world ( $\overline{\mathrm{x}} \pm \mathrm{s} ;$ standard deviation was not available for some values).

\begin{tabular}{|c|c|c|c|c|}
\hline Species & Location; Date & $\begin{array}{l}\text { Lead Content } \\
\text { in } \mathrm{mg} / \mathrm{Kg} \text { d.m }\end{array}$ & $\begin{array}{l}\text { Cadmium Content } \\
\text { in } \mathrm{mg} / \mathrm{Kg} \text { d.m }\end{array}$ & Context \\
\hline \multirow{5}{*}{$\begin{array}{l}\text { Xanthoria } \\
\text { calcicola }\end{array}$} & $\begin{array}{l}\text { Eastern Black Sea Region } \\
\text { (Turkey) } 2007\end{array}$ & $38.1 \pm \mathbf{3 . 3}$ & $0.17 \pm \mathbf{0 . 0 1}$ & Urban area, dense road traffic [26] \\
\hline & Girsun (Turquie) 2006 & 6,33 & & Zone urbain, trafic routier dense [27] \\
\hline & Macedonia (GREECE) 1995 & 125.2 & 0.8 & Industrial urban area plus road traffic [28] \\
\hline & Trabzon (Turkey) 2004 & 6.78 & 3.86 & Urban area, dense road traffic [29] \\
\hline & Safi (Morocco) 2018 & $30,18 \pm 4,15$ & $0,53 \pm 0,20$ & $\begin{array}{l}\text { Industrial urban area, road traffic (Essilmi et al } \\
\text { in litt) }\end{array}$ \\
\hline \multirow{2}{*}{$\begin{array}{l}\text { Xanthoria } \\
\text { polycarpa }\end{array}$} & Alger (Algeria) 2014 & 254,06 & 14,79 & Industrial urban area, road traffic [30] \\
\hline & Safi (Morocco) 2017 & $9,79 \pm 1,35$ & $0,58 \pm 0,23$ & Industrial urban area, road traffic (Essilmi et al) \\
\hline \multirow{2}{*}{$\begin{array}{l}\text { Ramalina } \\
\text { lacera }\end{array}$} & Israel 2003 & $8.5 \pm 1.7$ & & Coal-fired power station [31] \\
\hline & Safi (Morocco) 2018 & $3,35 \pm 0,74$ & $0,37 \pm 0,19$ & $\begin{array}{l}\text { Industrial urban area, road traffic (Essilmi et al } \\
\text { in litt) }\end{array}$ \\
\hline \multirow{3}{*}{$\begin{array}{l}\text { Ramalina } \\
\text { parietina }\end{array}$} & $\begin{array}{l}\text { Karabük, Turkey } \\
2014\end{array}$ & $1.7 \pm 0.008$ & $0.4 \pm 0.018$ & Industrial urban area, road traffic [32] \\
\hline & $\begin{array}{l}\text { Eastern Black Sea Region } \\
\text { (Turkey) } 2007\end{array}$ & $4.03 \pm 0.3$ & $0.25 \pm 0.02$ & Urban area, dense road traffic [26] \\
\hline & Safi (Morocco) 2018 & $4,36 \pm 0,27$ & $0,19 \pm 0,02$ & $\begin{array}{l}\text { Industrial urban area, road traffic (Essilmi et al } \\
\text { in litt) }\end{array}$ \\
\hline
\end{tabular}

These graphical analyses suggest 4 groups (clusters):

- A group consisting of the city center and the industrial zone (S3 and S4) (cluster1).

- A group consisting of borj nador sites, Safi coalfired power plant and Souiria (S2, S5 and S6) (cluster2).

- A group consisting of the site Oualidia (S1) (cluster4)

- A group consisting of Bhibah and Essaouira sites (S7 and S8) (cluster3).

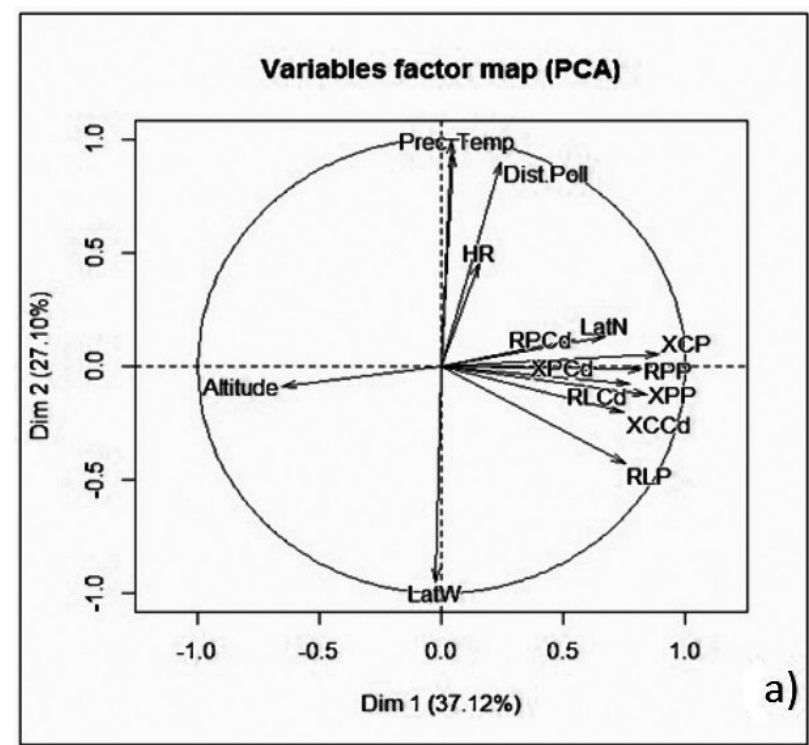

\section{Discussion}

In urban and industrial areas, pollutants cause damage to the photosynthesis apparatus [34], decrease the integrity of the cell membrane [35], decrease the photosynthetic pigments content [36] and can induce oxidative stress [37].

The average maximum levels of $\mathrm{Pb}$ bioaccumulation recorded at Safi shows that the foliose forms, Xanthoria calcicola $(30,18 \mathrm{mg} / \mathrm{Kg}$ d.m) and Xanthoria

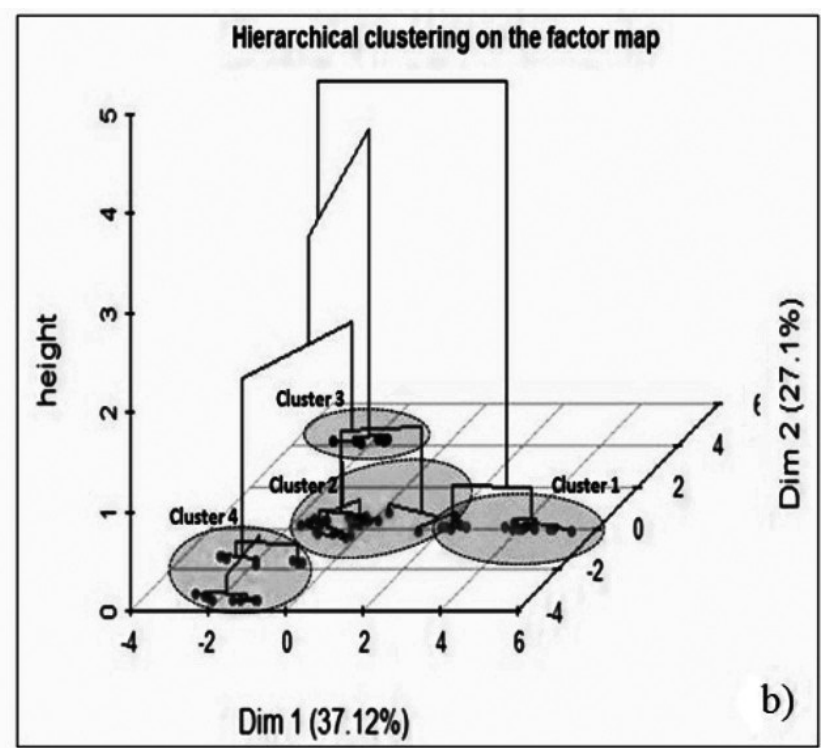

Fig. 3. a) Circle of correlations between variables; b) Hierarchical classification of the eight sites on the results of the factor analysis. 
parietina $(9,79 \mathrm{mg} / \mathrm{Kg}$ d.m.) accumulate more lead than the fruticose forms, Ramalina pollinaria (4,36 mg/Kg d.m.) and Ramalina lacera (3,35 mg/Kg d.m.). Idem for the $\mathrm{Cd}$, the foliose forms, Xanthoria calcicola $(0,53 \mathrm{mg} / \mathrm{Kg}$ d.m.) and Xanthoria parietina $(0,58 \mathrm{mg} / \mathrm{Kg}$ d.m.) accumulate more cadmium than the fruticose forms, Ramalina pollinaria $(0,19 \mathrm{mg} / \mathrm{Kg}$ d.m. and Ramalina lacera $(0,37 \mathrm{mg} / \mathrm{Kg}$ d.m.). This difference can be discussed at different levels.

At the Morphological Level: Studies have observed a relationship between the lichen growth form and its bioaccumulation capacity, and concluded that it is a key factor affecting models of MTE bioaccumulation in lichens [38].

Maizi et al. [39] reported that Ramalina farinacea is more sensitive to lead than Xanthoria parietina, and the absorption capacity of lead is different depending on the type of thallus (foliose or fruticose).

On Table 1 Xanthoria calcicola accumulates more lead than Xanthoria parietina: the relatively large thallus surface in X. calcicola increases its lead absorption capacity compared to $X$. parietina. Maatoug et al. [40] reported that lichens accumulate more metals as their surface increases. This may explain the greater uptake of elements directly from the atmosphere and their entrapment in the intercellular spaces of the thalli [41]; however, in the presence of a high level of lead, deformation of the thalli occurs with the appearance of chlorosis and sometimes even necrosis; this results in a decrease in photosynthesis and total chlorophyll concentration [39].

The disappearance of the fruticose forms from sites S3 and S4 can be related to the death of these lichens as a result of damage to their biological components.

At the Cellular Level: Alvarez et al. [42] reported that Ramalina farinacea shows a moderate tolerance to $\mathrm{Pb}$. Lead stress induces in this species a degradation of photosynthesis and photosynthetic pigments, a production of HSP70 protein and an increase in the formation of reactive oxygen species. In Ramalina fastigiata, cadmium accumulation results in a significant decrease in chlorophyll $\mathrm{a}$ and $\mathrm{b}$ levels and an increase in peroxidation of membrane lipids [43]. The disappearance of the Ramalina genus from the S3 and S4 sites could be linked to the ecological stress induced by air pollution, which has led to a degradation of cellular structures and a decrease of autotrophic potential.

At the Physiological Level: Lichens produce a variety of secondary metabolites, some of them located in the upper cortex, while most are located in the medulla [44]. These metabolites have antiherbivorous, antimicrobial and larvicidal properties, and can protect thalli from intense UV radiation and oxidative stress.

The bioaccumulation capacity of the genus Xanthoria is greater than that of the genus Ramalina (Table 1): In Xanthoria parietina, Kalinowska et al. [45] has demonstrated the protective role of parietin against $\mathrm{Cd}$ by producing non-protein thiol compounds (cysteine, glutathione and phytochelatines) involved in the detoxification of cadmium. Gauslaa et al. [46] reported that in polluted sites, the medullary metabolites in Ramalina farinacea have been reduced and lichen is less protected. Weissman et al. [47] reported that under conditions of low pollution, antioxidant activities occur in Ramalina lacera as protective mechanisms. However, after prolonged exposure, these protective mechanisms are overwhelmed and damage to cellular components begins to accumulate. This follows a decrease in antioxidant activities and degradation of lichen.

The disappearance of the Ramalina genus from the S3 and S4 sites may be related to the insufficiency or absence of secondary metabolites that may have a role in MTE homeostasis and tolerance pollution. The biochemical mechanisms of these metabolites are still poorly understood [48].

At the Molecular Level: In Xanthoria calcicola and Ramalina lacera, the low bioaccumulation levels recorded at Safi, compared to other regions of the world (Table 1), can be correlated with the existence of an interaction with other air pollutants; the "Office chérifien des phosphates" group [49], owner of the chemical industry "Maroc Phosphore", reported in its 2011 report that because of the industrial activities of Safi, the air quality will record the following values: NOx $28 \mu \mathrm{g} /$ $\mathrm{m}^{3}$ and $\mathrm{SO}_{2} 35 \mu \mathrm{g} / \mathrm{m}^{3}$. Measuring sulfur dioxide $\mathrm{SO}_{2}$ concentrations was carried out by the PHENIXA group in 2010 and calculated an average concentration of 50 $\mu \mathrm{g} / \mathrm{m}^{3}$ in site $\mathrm{S} 4$ [49].

It appears that in some urban contexts, although lichen can accumulate a high rate of MTE, the existence of a likely interaction with a second type of pollution may decrease its bioaccumulation potential. The gases $\mathrm{NOx}$ and $\mathrm{SO}_{2}$ are known to negatively affect the physiological status of lichens [50-51]. NOx and $\mathrm{SO}_{2}$ once in solution in lichen are powerful catalysts for membrane lipid peroxidation, which results in membrane damage [52-53]. These results indicate that a good lichenic bioaccumulation potential can be weakened by additional biochemical damage caused by other pollutants such as $\mathrm{NOx}$ and $\mathrm{SO}_{2}$.

At the Ecological Level: The average maximum levels of $\mathrm{Cd}$ bioaccumulation recorded at Safi shows that the corticolous forms $X$. parietina $(0,58 \mathrm{mg} / \mathrm{Kg}$ d.m.) accumulate more cadmium than the calcicolous forms $X$. calcicola $(0,53 \mathrm{mg} / \mathrm{Kg}$ d.m.); idem the corticolous forms $R$. lacera $(0,37 \mathrm{mg} / \mathrm{Kg}$ d.m. $)$ accumulate more cadmium than the calcicolous forms $R$. pollinaria (0,19 mg/Kg d.m.).

The unavailability of studies linking possible influence of the support on the bioaccumulation of $\mathrm{Cd}$ by lichens suggests the hypothesis of the influence of the support $\mathrm{pH}$. The model of higher plants shows that $\mathrm{Cd}$ has a more toxic effect under acidic than alkaline $\mathrm{pH}$ conditions [54-55]. It can be hypothesized that the alkaline character of the calcareous support for calcicolous forms (X. calcicola and R. pollinaria) 
reduces the toxicity of cadmium, while the relatively acidic character of the porophyte bark of the corticolous forms ( $X$. parietina and $R$. lacera) facilitates $\mathrm{Cd}$ bioaccumulation. For example, in a study on the presence of epiphytic lichens on oak and ash, Bates and Brown (1981) [56] found a negative correlation between bark $\mathrm{pH}$ and $\mathrm{Fe}$ concentration. They conclude that this correlation is due to the increased mobility of Fe when the $\mathrm{pH}$ of the bark decreases.

The study of the lichens potential as a biosorbents to remove MTE from the environment has shown that metal binding by lichens is highly $\mathrm{pH}$ dependent [57-60]; generally the optimal binding to MTE is observed at a $\mathrm{pH}$ of around 5, and this binding decreases relatively for $\mathrm{pH}$ values below 3 and above 7 .

Uluozlu et al. 2010 [57] reported that at low $\mathrm{pH}$, the biosorption yield may be due to competition for cell binding sites between hydronium ions and the cationic form of MTE, but when the $\mathrm{pH}$ becomes basic, the biosorption decreases and can be attributed to the competition, for sorption sites, between the hydroxyl ions and the anionic form of the MTE.

In Safi the presence of $\mathrm{SO}_{2}$ in the air and the humidity rate due to the proximity of the Atlantic are two factors that would favor the acidity of tree bark. The optimal acidic $\mathrm{pH}$ of the tree bark favors the biosorption of cadmium by lichens more than the calcareous support, whose $\mathrm{pH}$ is basic. Thus, the corticolous lichens accumulate more cadmium than the calcicolous forms.

\section{Spatial Variation of Air Quality}

Spatially, the measured levels of lead and cadmium were very high in urban sites S3 and S4 (Fig. 2); outside these sites these levels decrease in the peri-urban sites (S2 and S5) and the weakly urbanized municipalities (S6, S7, and S8), while these levels were very low at control site S1. This finding is confirmed by the HCPC analyses, which allowed for the distinction of four types of sites:

Group 1: constituted by the city center (S3) and the industrial zone (S4) of Safi where the rate of lead and cadmium bioaccumulated by the lichens was very high, testifies to poor air quality due to various industrial sectors (parachemical, agro-food, metallurgical, and textile industries). In addition to this industrial activity, the economic activities of a dense population of 691,983 inhabitants [61] and road traffic (4,804 vehicles [62] pollute the air and whose impact on the air quality is added to that of industrial origin).

Group 2: represented by localities with medium contamination in lead and cadmium and located at distances of 20 and $33 \mathrm{~km}$ from the industrial zone: this is the locality of Borj Nador (S2), the Safi coal-fired power plant (S5), and the municipality of Souiria (S6). These sites are poorly urbanized, non-industrialized and where the air quality is medium.

Group 3: represented by the municipality of Bhibah (S7) and the Essaouira city (S8), it indicates an air quality more or less influenced by low traffic (933 vehicles) and industrial processing activities (agro food, textile and leather, parachemical, and mechanical [63]).

Group 4: The site of Oualidia (District of Lakouassem): A rural site far from any industrial or urban impact, the activity of residents is focused on traditional agriculture, it is a site with good air quality and it has been chosen as a control site.

The study of bioaccumulation using lichens from this study area allowed for the deduction that group 1 is within a circle of $20 \mathrm{~km}$ and whose focus is the industrial zone and where the air quality is more or less disturbed by urbanization and industry; while Group 2 is in a circle of $40 \mathrm{~km}$ but $20 \mathrm{~km}$ away from the pollution focus and enjoying medium air quality. Group 3 and Group 4 are quite distant from the pollution focus and benefit from good air quality (Fig. 4). However, the air quality at the city of Essaouira (Site 8) seems to be contaminated by a lead contribution correlated mainly to road traffic.

Statistical tests showed that the bioaccumulation of $\mathrm{Cd}$ and $\mathrm{Pb}$ along the 8 sites does not follow a normal distribution, which can be explained by the existence of several sources generating air pollution. The sources of pollution to be considered are therefore:

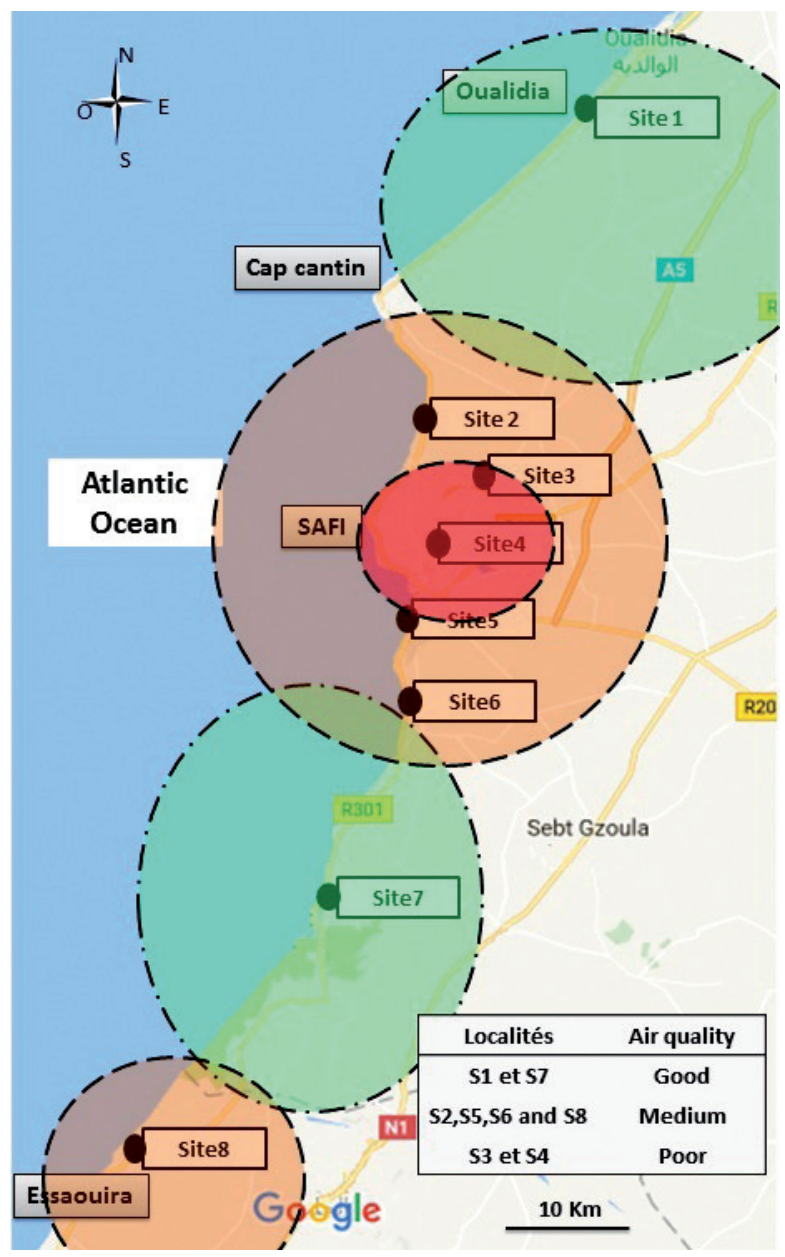

Fig. 4. Delimitation of sites according to their air quality. 
industrial activity and road traffic for the city of Safi, road traffic for the city of Essaouira, road traffic and agricultural input of phosphate fertilizers [64] containing Cadmium for the rest sites with the exception of the oualidia site (S1), which was chosen as a control site and where bioaccumulation rates are very low correlated with low agricultural input and low road traffic.

\section{Conclusions}

The maximum levels recorded for lead were $30.18 \mathrm{mg} / \mathrm{kg} \mathrm{DM} ; 4.36 \mathrm{mg} / \mathrm{kg} \mathrm{dm} ; 9.79 \mathrm{mg} / \mathrm{kg} \mathrm{dm}$; $3.35 \mathrm{mg} / \mathrm{kg} \mathrm{dm}$ respectively in Xanthoria calcicola, Ramalina pollinaria, Xanthoria parietina, and Ramalina lacera. The maximum levels recorded for cadmium were $0.53 \mathrm{mg} / \mathrm{kg} \mathrm{dm} ; 0.19 \mathrm{mg} / \mathrm{kg} \mathrm{dm}$; $0.58 \mathrm{mg} / \mathrm{kg} \mathrm{dm}$; and $0.37 \mathrm{mg} / \mathrm{kg} \mathrm{dm}$ in Xanthoria calcicola, Ramalina pollinaria, Xanthoria parietina, and Ramalina lacera respectively. Morphologically, the foliose forms (Xanthoria calcicola and Xanthoria parietina) accumulate more lead and cadmium than the fruticose forms (Ramalina pollinaria and Ramalina lacera). If MTE is the only source of pollution, lichen can accumulate high MTE levels, but if damage is caused by other pollutants, lichen sees its potential for a bioaccumulation decrease. Unlike foliose lichens, the disappearance of fruticose lichens faced with a high rate of MTE is due to the insufficiency of their cellular protective mechanisms.

The air pollution of the Atlantic coast Safi-Essaouira seems to be correlated with the road traffic, the degree of urbanization and the economic activity of the region. The evaluation of bioaccumulation using four lichen species has allowed for the highlighting of an alteration of air quality in the urban and industrial zone of Safi; however, the geographical remoteness of this zone is reflected in a remarkable lichenic contents decrease of lead and cadmium.

Along a decreasing gradient of pollution from urban areas following the dilution of pollution to the north and to the south, we can retain three levels of air quality: poor air quality in the industrial site of Safi, medium air quality in peri-urban areas and the city of Essaouira, and good quality air in the rural sites.

This study demonstrates the perfect adequacy of lichens as bioaccumulators for mapping air quality and locating sources of pollution. The originality of this approach is that it allowed for the simultaneous monitoring of two chemical contaminants $(\mathrm{Pb}$ and $\mathrm{Cd}$ ) in four species of lichens on an inter-municipal territory.

\section{Acknowledgements}

We warmly thank members of the French association of lichenology (AFL) for their contribution to the identification of certain species during the determination session at the laboratory of the forest ecology station of Fontainebleau (France, 2016).

\section{Conflict of Interest}

The authors declare no conflict of interest.

\section{References}

1. World Health Organization (WHO). WHO releases country estimates on air pollution exposure and health impact. Available online: http://www.who.int/news-room/ detail/27-09-2016-who-releases-country-estimates-onair-pollution-exposure-and-health-impact (accessed on 25 February 2018).

2. CETIN M., SEVIK H. Measuring the Impact of Selected Plants on Indoor CO Concentrations. Polish Journal of Environmental Studies, 25 (3), 973, 2016.

3. CETIN M., SEVIK H. Change of air quality in Kastamonu city in terms of particulate matter and $\mathrm{CO}$ amount. Oxidation Communications 39, (4-II), 3394, 2016.

4. CETIN M., SEVIK H., ISINKARALAR K. Changes in the particulate matter and $\mathrm{CO}$ concentrations based on the time and weather conditions: the case of Kastamonu. Oxidation Communications, 40 (1-II), 477, 2017.

5. State Secretariat to the Minister of Energy, Mines and Sustainable Development, in charge of Sustainable Development. Morocco. Pollution de l'air. 2015. Available online: http://www.environnement.gov.ma/fr/ air (accessed on 25 February 2018)

6. NIMIS P.L., SCHEIDEGGER C., WOLSELEY P.A. Monitoring with Lichens. 2000. Available Book online: https://books.google.co.ma/ b o o k s ? id = J r u L B Q A A Q B A J \& 1 p g $=$ P A 65 \& ots $=$ Z7diBV7DVK\&dq=lichen $\% 20$ good $\% 20$ accumulato $\mathrm{r} \& \mathrm{hl}=$ fr\&pg $=$ PA65\# $\mathrm{v}=$ onepage $\& \mathrm{q}=1$ ichen $\% 20 \operatorname{good} \% 20$ accumulator\&f=false (accessed on 5 February 2018).

7. JUN Y.S., JEONG C.H., SABALIAUSKAS K., LEAITCH W.R., EVANS G.J. A year-long comparison of particle formation events at paired urban and rural locations. Atmospheric Pollution Research, 447, 2014.

8. SEVIK H., AHMAIDA E.A., CETIN M. Change of the Air Quality in the Urban Open and Green Spaces: Kastamonu Sample. Ecology, Planning and Design. Chapter 31. Eds: Irina Koleva, Ulku Duman Yuksel, Lahcen Benaabidate, St. Kliment Ohridski University Press, ISBN: 978-954074270-0, 409, 2017

9. CETIN M., MOSSI M.M.M., AKBUDAK K.Y. Visual Examination of Natural and Cultural Landscape Values in Kastamonu City Center for Sustainable Spatial Development. Ecology, Planning and Design. Chapter 35. Eds: Irina Koleva, Ulku Duman Yuksel, Lahcen Benaabidate, St. Kliment Ohridski University Press, ISBN: 978-954-07-4270-0, 465, 2017

10. NIMIS P.L., MARTELLOS S. ITALIC 5.0, the information system on Italian Lichens. University of Trieste, Dept. of Biology, http ://dryades.units.it/italic. (accessed on october 2017).

11. ESSILMI M., LOUDIKI M., ELGHARMALI A. Qualitative estimate of global air pollution in the city of Safi (Moroccan Atlantic coast) through the use of 
saxicolous lichens, Bull. Soc. linn.Provence, t. 68, ISSN 0373-0875, 2017.

12. SUJETOVIENE G. Recent advances in lichenology: modern methods and approaches in biomonitoring and bioprospection; Springer India; New Delhi, India, 87, 2015.

13. ROLA K., OSYCZKA P., NOBIS M. Cryptogamic Communities Dominated by the Lichen Cladonia rei - a Case Study of Polish Post-Smelting Dumps in a Worldwide Context. Herzogia. 27. 121-135. 10.13158/ heia.27.1.2014.121. 2014.

14. BAJPAI R., KARAKOTI N., UPRETI D.K. Performance of naturally growing Parmelioid lichen Remototrachyna awasthii against organic and inorganic pollutants. Environ Sci Pollut Res. 20:5577-5592. doi: 10.1007/s11356-0131583-3. 2013.

15. NAKAJIMA H., HARA K., YAMAMOTO Y., ITOH $\mathrm{K}$. Effects of $\mathrm{Cu}$ on the content of chlorophylls and secondary metabolites in the $\mathrm{Cu}$-hyperaccumulator lichen Stereocaulon japonicum. Ecotox Environ Safe. 113:477482. doi: 10.1016/j.ecoenv.2014.12.038. 2015.

16. PAOLI L., GUTTOVÁ A., SORBO S., GRASSI A., LACKOVIČOVÁ A., BASILE A., SENKO D., LOPPI S. Vitality of the cyanolichen Peltigera praetextata (Sommerf.) Zopf exposed around a cement plant (SW Slovakia): a comparison with green algal lichens. Biologia. 71:272-280. doi: 10.1515/biolog-2016-0059. 2016.

17. PAOLI L., GUTTOVÁ A., GRASSI A., LACKOVIČOVÁ A., SENKO D., SORBO S., BASILE A., LOPPI S. Ecophysiological and ultrastructural effects of dust pollution in lichens exposed around a cement plant (SW Slovakia) Environ Sci Pollut R. 20:15891-15902. doi: 10.1007/s11356-015-4807-x. 2015.

18. MATEOS A.C., GONZÁLEZ C.M. Physiological response and sulfur accumulation in the biomonitor Ramalina celastri in relation to the concentrations of $\mathrm{SO}_{2}$ and $\mathrm{NO}_{2}$ in urban environments. Microchem J125:116-123. doi: 10.1016/j.microc.2015.11.025. 2016.

19. GUTTOVA A., LACKOVICOVA A., PISUT I., PISUT P. Decrease in air pollution load in urban environment of Bratislava (Slovakia) inferred from accumulation of metal elements in lichens. Environmental monitoring and assessment 182:361. https://doi.org/10.1007/s10661-0111881-5. 2011

20. OZTETIK E., CICEK A. Effects of urban air pollutants on elemental accumulation and identification of oxidative stress biomarkers in the transplanted lichen Pseudovernia furfuracea. Environmental Toxicology and Chemistry 30, 1629, 2011.

21. DEMIRAY A.D., YOLCUBAL I., AKYOL N.H., COBANOGLU G. Biomonitoring of airborne metals using the lichen Xanthoria parietina in Kocaeli province,Turkey. Ecological Indicators 18, 632, 2012.

22. HAUCK M., BONING J., JACOB M., DITTRICH S., FEUSSNER I., LEUSCHNER C. Lichen substance concentrations in the lichen Hypogymnia physodes are correlated with heavy metal concentrations in the substratum. Environmental and Experimental Botany, 85, $58,2013$.

23. El RHZAOUI G., DIVAKAR P.K., CRESPO A., TAHIRI H., El ALAOUI-FARIS F.E. Xanthoria parietina as a biomonitor of airborne heavy metal pollution in forest sites in the North East of Morocco. Lazaroa 36, 13, 2015.

24. ALAMI F.Z.O., ELABIDI A., MOUHIR L., FEKHAOUI M., SERGHINI A. Utilisation des lichens comme bio-indicateurs de la pollution atmosphérique par le plomb, cadmium et zinc de la région de Rabat-Sale-ZemmourZaêr (Maroc), Afrique SCIENCE 10 (3) 89, 2014.

25. MONNA F., BOUCHAOU L., RAMBEAU C., REMI L., BRUGUIER O., DONGARRÀ G., BLACK S., CHATEAU C. Lichens used as monitors of atmospheric pollution around Agadir (Southwestern Morocco)? A case study predating lead-free gasoline, Water Air and Soil Pollution, 223, 1263-1274.10.1007/s11270-011-0942-2. 2011.

26. ULUOZLU O.D., KINALIOGLU K., TUZEN M., SOYLAK M. Trace metal levels in lichen samples from roadsides in East Black Sea region, Turkey. Biomedical Environmental Sciences. 20, 203, 2007.

27. KINALIOĞLU K., HORUZ A., KUTBAY G., BILGIN A., YALÇIN E. Accumulation of some heavy metals in lichens in Giresun city, Turkey. Ekologia Bratislava. 25, 306, 2006

28. SAWIDIS T., CHETTRI M.K., ZACHARIADIS G.A., STRATIS J.A., SEAWARD M.R.D. Heavy metal bioaccumulation in lichens from Macedonia in northern Greece. Toxicol. Environ. Chem., 50, 157, 1995.

29. DEMIRBAŞ A. Trace Element Concentrations in Ashes from Various Types of Lichen Biomass Species. Energy Sources. 26. 499-506. doi:10.1080/00908310490429687. 2004.

30. SARMOUM M., DJEBBAR R., LATRECH K. Bioaccumulation of three heavy metals $(\mathrm{Pb}, \mathrm{Zn}$ and $\mathrm{Cd})$ by lichen, Xanthoria parietina in the Algroise region. Ecology Environment Review. 10, 25, 2014.

31. GARTY J., TOMER S., LEVIN T., LEHR H. Lichens as biomonitors around a coal-fired power station in Israil. Environ. Res. 91, 186, 2003.

32. DUMAN D.C., ALTUNKAYNAK E., ARAS E.S. Heavy metal accumulation and genotoxicity indicator capacity of the lichen species Ramalina pollinaria collected from around an iron steel factory in Karabük, Turkey. Turk. J. Bot., 38, 14, 2014.

33. HUSSON F., JOSSE J., PAGÉS J. Principal component methods-hierarchical clustering partitional clustering: why would we need to choose for visualizing data?. Technical Report-Agrocampus, Applied Mathematics Department. 2010.

34. PICCOTTO M., BIDUSSI M., TRETIACH M. Effects of the urban environmental conditions on the chlorophylla fluorescence emission in transplants of three ecologically distinct lichens. Environmental and Experimenta 1Botany 73, 102, 2011.

35. PAOLI L., PISANI T., GUTTOVA A., SARDELlA G., LOPPI S. Physiological and chemical response of lichens transplanted in and around an industrial area of south Italy: relationship with the lichen diversity. Ecotoxicology and Environmental Safety 74, 650, 2011.

36. BACKOR M., KOVACIK J., PIOVAR J., PISANI T., LOPPI S. Physiological aspects of cadmium and nickel toxicity in the lichens peltigera rufescens and cladina arbuscula sub sp mitis. Water Air and Soil Pollution 207, 253, 2010.

37. OZTETIK E., CICEK A. Effects of urban air pollutants on elemental accumulation and identification of oxidative stress biomarkers in the transplanted lichen Pseudovernia furfuracea. Environmental Toxicology and Chemistry 30, 1629, 2011.

38. CLAIR S.B., CLAIR L.L., MANGELSON N.F., WEBER D.J., EGGETT D.L. Element accumulation patterns in foliose and fruticose lichens from rock and bark substrates in Arizona. Bryologist 105, 415, 2002. 
39. MAIZI N., KADRI N., SERRADJ M. Absorption capacity of lead by different lichenic species. Int. J. Biosci. 10 (2), 61-71, February 2017.

40. MAATOUG M., TAÏBI K., AKERMI A., ACHIR M., MESTRARI M. Bio-Monitoring of Air Quality Using Leaves of Tree and Lichens in Urban Environments, Air Pollution - Monitoring, Modelling and Health, Dr. Mukesh Khare (Ed.), ISBN: 978-953-51-0424-7, InTech. 2012.

41. BERTUZZI S., TRETIACH M. Hydrogen sulphide inhibits PSII of lichen photobionts. Lichenologist 45, 101, 2013.

42. ÁlVAREZ R., DEL HOYO A., GARCÍA-BREIJO F., REIG-ARMI N.J., DEL CAMPO E.M., GUÉRA A., BARRENO E., CASANO L.M. Different strategies to achieve $\mathrm{Pb}$-tolerance by the two Trebouxia algae coexisting in the lichen Ramalina farinacea. Journal of plant physiology. 169 (18), 1797, 2012.

43. SUJETOVIENE G., ŠLIUMPAITE I. Effects of Cadmium on Physiological Parameters of the Lichen Evernia Prunastri and Ramalina Fastigiata. E3S Web of Conferences. 1. 10.1051/e3sconf/20130129007. 2012

44. SOLHAUG K.A., LIND M., NYBAKKEN L., GAUSLAA Y. Possible functional roles of cortical depsides and medullary depsidones in the foliose lichen Hypogymnia physodes. Flora-Morphology, Distribution, Functional Ecology of Plants 204, 40, 2009.

45. KALINOWSKA R., BAČKOR M., PAWLIKSKOWROŃSKA B. Parietin in the tolerant lichen Xanthoria parietina (L.) Th. Fr. increases protection of Trebouxia photobionts from cadmium excess. Ecological Indicators. 58. 10.1016/j.ecolind.2015.05.055. 2015.

46. GAUSLAA Y., YEMETS O.A., ASPLUND J., SOLHAUG K.A. Carbon based secondary compounds do not provide protection against heavy metal road pollutants in epiphytic macrolichens. Science of the Total Environment 541, 795, 2016.

47. WEISSMAN L., FRAIBERG M., SHINE L., GARTY J., HOCHMAN A. Responses of antioxidants in the lichen Ramalina lacera may serve as an early-warning bioindicator system for the detection of air pollution stress, FEMS Microbiology Ecology. 58 (1), 41, 2006.

48. MOLNÁR K., FARKAS E. Current results on biological activities of lichen secondary metabolites: a review. Zeitschrift für Naturforschung C 65, 157, 2010.

49. Office chérifien des phosphates (OCP, Morocco). Étude d'impact sur l'environnement. Rapport 2010_26245/EIE_ PS4,107 p. 2011.

50. DAS K., DEY U., BHAUMIK R., DATTA J.K., MONDAL N.K. A comparative study of lichen biochemistry and air pollution status of urban, semi urban and industrial areas of Hooghly and Burdwan district, West Bengal. Journal of Stress Physiology and Biochemistry, 7 (4), 311, 2011.

51. PAOLI L., BENESPERI R., PROIETTI P.D., CORSINI A., LOPPI S. Biological effects of ammonia released from a composting plant assessed with lichens. Environmental Science and Pollution Research International, 21 (9), 5861, 2014.

52. RIGA-KARANDINOS A.N., KARANDINOS M.G. Assessment of air pollution from a lignite power plant in the plain of Megalopolis (Greece) using as biomonitors three species of lichens; impacts on some biochemical parameters of lichens. Science of the Total Environment,
215:167-183. Doi.org/10.1016/S0048-9697(98)00119-3. 1998.

53. FAVALI M., CORRADI M., FOSSATI F. X-ray microanalysis and ultrastructure of lichens from polluted and unpolluted areas. Plants for Toxicity Assessment, Vol. II. Philadelphia, USA, 1115: 276-284. 1991.

54. SONG Y., LUO Z., CHEN Q.L., LIU X., LIU C.X., ZHENG J.L. Protective Effects of Calcium Pre-Exposure Against Waterborne Cadmium Toxicity in Synechogobius hasta. Archives of environmental contamination and toxicology. 65. 10.1007/s00244-013-9883-7.D. 2013.

55. BENABID H., GHORAB M.F. Study of the Effect of $\mathrm{pH}$ on the Toxicity and Bioaccumulation of Cadmium on Beans [Phaseolus Vulgaris]. International Journal of Environmental Science and Development. 5. 463, 10.7763/ IJESD.2014.V5.528. 2014.

56. BATES J.W., BROWN D.H. Epiphyte differentiation between Quercus petraea and Fraxinus excelsior trees in a maritime area of South West England. Vegetatio 48, 6170, 1981.

57. ULUOZLU O.D., SARI A., TUZEN M. Biosorption of antimony from aqueous solution by lichen (Physcia tribacia) biomass Chemical Engineering Journal, 163 (3), 382, 2010.

58. TUZEN M., SARI A., MENDIL D., SOYLAK M. Biosorptive removal of mercury(II) from aqueous solution using lichen (Xanthoparmelia conspersa) biomass: Kinetic and equilibrium studies Journal of Hazardous Materials, 169 (1-3), 263, 2009.

59. ULUOZLU O.D., SARI A., TUZEN M., SOYLAK M. Biosorption of $\mathrm{Pb}(\mathrm{II})$ and $\mathrm{Cr}(\mathrm{III})$ from aqueous solution by lichen (Parmelina tiliaceae) biomass. Bioresource Technology, 99 (8), 2972, 2008.

60. SARI A., TUZEN M., ULUOZLU O.D., SOYLAK M. Biosorption of $\mathrm{Pb}(\mathrm{II})$ and $\mathrm{Ni}(\mathrm{II})$ from aqueous solution by lichen (Cladonia furcata) biomass Biochemical Engineering Journal, 37 (2), 151, 2007.

61. Haut - Commissariat au Plan, Safi province. Provincial Direction Publications of Safi City. Available online: https://www.hcp.ma/region-drda/Publications-delaDirection-Proviciale-de-Safi_a2.html (accessed on 22 Aout 2018).

62. Ministry of Equipment, Transport and logistic, Monograph of the Marrakech - Safi region. Available online http:// www.pncl.gov.ma/fr/lescollectivit\%c3\%a 9 sterrito riales/ documents/ monograpphie $\% 20$ de $\% 201 \mathrm{a} \% 20$ region de marrakech-safi.pdf. (accessed on 22 Aout 2018).

63. Local monograph on the environment of Essaouira. National Observatory of the Environment of Morocco (ONEM). Available online: https://d1n7iqsz6ob2ad. cloudfront.net/document/pdf/5385c31bb7141.pdf. (accessed on 22 Aout 2018).

64. Goodplanet. Cadmium, this silent, hidden killer in phosphate fertilizers. 2018. Available online: https:// www.goodplanet.info/debat/2018/03/16/le-cadmiumcetueur-silencieux-cache-dans-les-engrais-phosphates/ (accessed on April 2018).Ministère de l'Equipement, du Transport et de la Logistique. Monographie de la region marrakech-safi. Available online: http://www.pncl.gov. $\mathrm{ma} / \mathrm{fr} /$ lescollectivit\%c3\%a9sterrito riales/documents/ monograpphie $\% 20 \mathrm{de} \% 201 \mathrm{a} \% 20$ region $\% 20 \mathrm{de} \% 20$ marrakech\%20safi.pdf. (accessed on 22 Aout 2018). 